\title{
Impact of Rice Pudding on Preschool-Aged Children's Health: an Overview of a Pilot Study
}

\author{
Jib Acharya ${ }^{1 *}$, Edwin van Teijlingen ${ }^{1}$, Basma Ellahi ${ }^{2}$, Bishnu Pariyar $^{3}$, Krishna Subedi $^{4}$ and Mohan Dangal ${ }^{4}$ \\ ${ }^{1}$ Faculty of Health and Social Sciences, Bournemouth University, England \\ ${ }^{2}$ Faculty of Health and Social Care, University of Chester, England \\ ${ }^{3}$ School of Geography, University of Leeds, England \\ ${ }^{4}$ Child Nepal, Kathmandu, Nepal
}

Received: 此 June 18, 2018; Published: 紫July 05, 2018

*Corresponding author: Jib Acharya, Faculty of Health and Social Sciences, Bournemouth University, Dorset, England, P.O. Box No.: 21829 GPO Kathmandu, Nepal

\section{Abstract}

Background: Preschool-aged children of disadvantaged households in Nepal have a higher prevalence rate of under nutrition. A major contributing reason is the inadequate maternal knowledge, existing taboos and unscientific food recommendation practices.

Aim: This pilot study evaluates the impact of the rice pudding feeding programme on child health and calculates the costs of the preparation

Materials and Methods: A before-and-after study of children aged under-five attending a day-care centre in remote Nepal. Children's weight, height and MUAC (Mid-Upper Arm Circumference) were compared before and after the rice pudding programme which lasted 54 days.

Results: 42 children (boys $43 \%$ \& girls 57\%), of whom $90 \%$ had gained weight whilst the weight of the remaining $10 \%$ of children stayed constant. Similarly, $78 \%$ had increased MUAC while $12 \%$ of 2 children improved slightly. The study was inexpensive, US\$ 0.34 per day per child and likely to be cost-effective.

Conclusion: A regular healthy diet of rice pudding helps children's nutritional need. It is important to consider right dietary practice, including portion sizes, and community awareness about healthy diet and impact of child health as well as sustainability.

Key Messages

a) Significantly improved child's weight and MUAC.

b) Partnership programme leads to cost-effectiveness and sustainability of the programme.

c) This programme could be replicated in the similar areas in Nepal.

Keywords: Rice Pudding; Healthy Diet; Knowledge; Beliefs; Attitudes; Poverty; School Meal and Malnutrition; Child Health; Well-Nourished Children; Preservatives; Artificial Flavouring; Synthetic Chemicals; Mobilization; Innovation; Portable Stadiometer

\section{Introduction}

Most children who suffer from hunger, infections, most other diseases, or who are deficient in certain nutrients do not have the same potential for cognitive skill development as well-nourished children [1-4]. Good nutritional and health status have a powerful effect on how well a student performs and learns at school [4-6]. Poor nutrition among school-aged children impairs their learning and development through poor participation in learning experiences, physiological changes, or both [5,6,7]. Research highlights a link between under-nutrition, as a determinant for poor health, and the educational performance of school children [8-12].

\section{Study Rationale}

In 2013, the World Food Programme (WFP) estimated that nearly 368 million children from developing and developed countries received a meal every day at school, at an annual cost of School USD 45 to 75 billion [12] the school meals programme plays a crucial role in the diets of children in poor families. This study targeted the following aspects: evaluation of the anthropometric changes of the under-five children, [12,13,14] assessment of the costs of the rice pudding meals, raising awareness about a healthy 3 diet $[16,20]$. It ultimately aimed to support Sustainable Development Goals 2, 3 and 5 [1,13-16] In order to inform 
intervention plans, a pilot study was undertaken as the first step to begin building an appropriate evidence base on improving child health and food behaviour [4,9,13,17-19].

\section{Objectives}

This study focused on addressing child hunger and micronutrient deficiencies, both of which can impact weight, height and MUAC (Mid-Upper Arm Circumference) [3,17,14,20,21] through the provision of rice pudding as a meal in schools. It set out to address three aspects:

a) Evaluate the impact of the rice pudding feeding programme on child health.

b) Calculate the costs of the preparation.

c) Increase the level of awareness about a healthy diet and local involvement in the school snack programme.

\section{Materials and Methods}

\section{Study design}

The pilot study [22,23] aimed to evaluate and compare the anthropometric progress of children under five. All the children who enrolled at Jugal Child Development Center (CDC) were included in the study [24].

\section{Study population and exclusion criteria}

This study selected the Jugal Child Development Center (CDC) of Sindhupalchowk district of Nepal and recruited 42 children $[25,26]$. There were no declines or withdrawals after the start of the study $[22,4]$.

\section{Duration}

The study started on 21 December 2015 and ended on 21 February 2016. The rice pudding was served for 54 days during the Tiffin (snack) time between 12:00 to 13:00 pm.28 The CDC opened Sunday to Friday from 9:00-15:00 hrs.

\section{Rice pudding preparation and portion size}

Rice pudding29 was prepared according to a traditional recipe with some additional ingredients to enhance nutritional value and improve taste. Preservatives, artificial flavouring and other synthetic chemicals were avoided [3,5,27-29] A metal cup was used to measure the portion (300 grams/child) of rice pudding.1 This study did not calculate the calorific content and nutritional information of all the additives $[1,19,20,26]$ The rice pudding contained dry fruits, sugar, and other ingredients (Table 1). During the intervention, CDC facilitators took the lead role in preparing the rice pudding while mothers assisted in its preparation. Child Nepal (a non-governmental organization) played a crucial role in community mobilization/innovation [26]. The milk for the rice pudding was obtained by mothers from local farmers at a subsidised rate. Other necessary kitchen accessories and fuel for cooking were secured by CDC in collaboration with mothers $[25,26,29,30]$. It is estimated that the total cost for 300 grams of rice pudding was US\$0.34 day/child or Nepali Rupees (NR) 35.50. This cost (Table 1) included materials, management, fuel and labour costs $[11,12,17,31,32]$, the estimated cost was US\$ 14.36 per day for the 42 children (Table 1). The labour cost was subsidised by the local body, particularly by the CDC and mothers' group. There was no or very limited data on the costs for school snacks programmes available in Nepal [5].

Table 1: Description of the materials cost for the rice pudding (daily).

\begin{tabular}{|c|c|c|c|}
\hline Particulars & Unit & Cost (NRs) & Total (USD) \\
\hline Clarified butter & $500 \mathrm{ml}$ & 250 & 2.39 \\
\hline Raisins & $200 \mathrm{mg}$ & 50 & 0.48 \\
\hline Sugar & $1 \mathrm{Kg}$ & 80 & 0.76 \\
\hline Rice & $1 \mathrm{Kg}$ & 100 & 0.96 \\
\hline Coconut & $250 \mathrm{mg}$ & 25 & 0.24 \\
\hline Cashew-nut & $200 \mathrm{mg}$ & 500 & 4.79 \\
\hline Cinnamon & $50 \mathrm{mg}$ & 15 & 0.14 \\
\hline Milk & 10 Liters & 400 & 3.83 \\
\hline Miscellaneous & Fuel and labour charges & 80 & 0.77 \\
\hline $\begin{array}{l}\text { Subtotal (daily expenses for } 42 \\
\text { children) }\end{array}$ & & 1500 & 14.36 \\
\hline Total cost & USD 0.34 day/child (NRs 35.51) & 1500 x 54days $=81,000$ & $\begin{array}{c}775.56 \text { (1USD@ 104.44 NRs. on } 20 \\
\text { Dec. 2015) }\end{array}$ \\
\hline
\end{tabular}

Note: There was no fixed market price available in Nepal; hence price is based on costs as local markets.

\section{Training and consent}

Health workers and CDC teachers underwent training on data collection and recording. Similarly, they were aware of the importance of the healthy diet (rice pudding) and also of the study [32]. The District Public Health Office and District Education Office of Sindhupalchowk of Nepal have approved the ethical permission for this study and consent were obtained from all parents and guardians prior to the rice pudding distribution programme $[8,28,29]$. Prior to start the study, the corresponding author had taken a consent from his supervisory team, who reviewed the study proposal of Bournemouth University. 


\section{Results}

\section{Health and anthropometric measurements}

Participating children's general health was assessed, and the results were normal [2,33,25]. Weight, height and MUAC assessments were undertaken twice by an experienced health professional $[1,35]$ at baseline and upon completion of the study and recorded in the data record form (Table 2). Height and MUAC for children measurements were recorded in centimetres $(\mathrm{cm})$
(Tables 2\&3). Heights of children were measured using a portable stadiometer (Seca) and recorded to the nearest one decimal place [16] similarly; MUAC was measured using a simple and a portable measuring tape and recorded to the nearest single decimal place. Weight was measured on a SECA 882 digital scale and recorded to the nearest $0.1-\mathrm{kg}$. Weighing scales were standardized with a $5-\mathrm{kg}$ weight at the beginning of each testing day. All children were dressed in light clothing and standard procedures and equipment were used $[16,6]$.

Table 2: Data record form.

\begin{tabular}{|c|c|c|c|c|c|c|c|c|c|}
\hline S.No. & $\begin{array}{c}\text { Name of the } \\
\text { Child }\end{array}$ & Sex(M/F) & $\begin{array}{c}\text { Age in } \\
\text { Months }\end{array}$ & \multicolumn{2}{|c|}{ Initial data record } & \multicolumn{3}{|c|}{ Final data record } \\
\hline & & & & Weight (Kg) & Height (Cm) & $\begin{array}{c}\text { MUAC } \\
\text { (Cm) }\end{array}$ & Weight (Kg) & Height (Cm) & $\begin{array}{c}\text { MUAC } \\
\text { (Cm) }\end{array}$ \\
\hline & & & & & & & & & \\
\hline & & & & & & & & & \\
\hline
\end{tabular}

Table 3: Demographics and data records of the participants.

\begin{tabular}{|c|c|c|c|c|c|c|c|c|c|}
\hline \multirow[t]{2}{*}{ S.No. } & \multirow[t]{2}{*}{$\begin{array}{c}\text { Name of the } \\
\text { Child }\end{array}$} & \multirow[t]{2}{*}{$\begin{array}{l}\text { Gender } \\
(\mathrm{M} / \mathrm{F})\end{array}$} & \multirow[t]{2}{*}{$\begin{array}{c}\text { Age } \\
\text { (Months) }\end{array}$} & \multicolumn{3}{|c|}{ Initial data } & \multicolumn{3}{|c|}{ Final data } \\
\hline & & & & Weight (Kg) & Height $(\mathrm{Cm})$ & $\begin{array}{l}\text { MUAC } \\
(\mathrm{Cm})\end{array}$ & Weight (Kg) & Height (Cm) & $\begin{array}{l}\text { MUAC } \\
(\mathrm{Cm})\end{array}$ \\
\hline 1 & & $\mathrm{~F}$ & 56 & $14 \mathrm{~kg}$ & $91 \mathrm{~cm}$ & $17 \mathrm{~cm}$ & 15 & 92.5 & 18.8 \\
\hline 2 & & $\mathrm{~F}$ & 59 & $16 \mathrm{~kg}$ & $95.3 \mathrm{~cm}$ & $18.2 \mathrm{~cm}$ & 16 & 95.7 & 18.9 \\
\hline 3 & & M & 48 & $15 \mathrm{~kg}$ & $92 \mathrm{~cm}$ & $17 \mathrm{~cm}$ & 16 & 93 & 17.4 \\
\hline 4 & & M & 60 & $16 \mathrm{Kg}$ & $97.2 \mathrm{~cm}$ & $18 \mathrm{~cm}$ & 17 & 98 & 18.8 \\
\hline 5 & & $\mathrm{~F}$ & 60 & $15 \mathrm{~kg}$ & $95 \mathrm{~cm}$ & $18 \mathrm{~cm}$ & 16.3 & 95.8 & 19 \\
\hline 6 & & $\mathrm{~F}$ & 49 & $13 \mathrm{~kg}$ & $89.5 \mathrm{~cm}$ & $15.4 \mathrm{~cm}$ & 14.5 & 90 & 16.2 \\
\hline 7 & & $\mathrm{~F}$ & 50 & $15 \mathrm{~kg}$ & $91.3 \mathrm{~cm}$ & $15 \mathrm{~cm}$ & 16 & 92 & 16 \\
\hline 8 & & M & 59 & $16 \mathrm{~kg}$ & $90 \mathrm{~cm}$ & $18 \mathrm{~cm}$ & 16.4 & 91 & 19 \\
\hline 9 & & M & 60 & $16 \mathrm{~kg}$ & $91.5 \mathrm{~cm}$ & $18.5 \mathrm{~cm}$ & 17 & 92.4 & 19.1 \\
\hline 10 & & $\mathrm{~F}$ & 42 & $14 \mathrm{~kg}$ & $89 \mathrm{~cm}$ & $16.6 \mathrm{~cm}$ & 14.2 & 90.5 & 17.2 \\
\hline 11 & & M & 49 & $14 \mathrm{~kg}$ & $91.4 \mathrm{~cm}$ & $18 \mathrm{~cm}$ & 15 & 92 & 18.7 \\
\hline 12 & & $\mathrm{~F}$ & 60 & $14 \mathrm{~kg}$ & $96.1 \mathrm{~cm}$ & $18.6 \mathrm{~cm}$ & 15.5 & 96.6 & 19 \\
\hline 13 & & M & 49 & $18 \mathrm{~kg}$ & $98 \mathrm{~cm}$ & $18 \mathrm{~cm}$ & 18 & 98 & 19 \\
\hline 14 & & $M$ & 60 & $15 \mathrm{~kg}$ & $95.5 \mathrm{~cm}$ & $18 \mathrm{~cm}$ & 16.5 & 96.3 & 19.2 \\
\hline 15 & & $\mathrm{~F}$ & 49 & $14 \mathrm{~kg}$ & $85 \mathrm{~cm}$ & $16.5 \mathrm{~cm}$ & 14 & 85.5 & 17 \\
\hline 16 & & $\mathrm{~F}$ & 47 & $15 \mathrm{~kg}$ & $84.8 \mathrm{~cm}$ & $16 \mathrm{~cm}$ & 16 & 85.2 & 17 \\
\hline 17 & & $M$ & 49 & $15 \mathrm{~kg}$ & $84 \mathrm{~cm}$ & $16 \mathrm{~cm}$ & 15.5 & 85 & 16.8 \\
\hline 18 & & $\mathrm{~F}$ & 49 & $13 \mathrm{~kg}$ & $84.4 \mathrm{~cm}$ & $15 \mathrm{~cm}$ & 13 & 85 & 16 \\
\hline 19 & & $M$ & 49 & $15 \mathrm{~kg}$ & $91.1 \mathrm{~cm}$ & $17 \mathrm{~cm}$ & 15.5 & 92 & 18 \\
\hline 20 & & $\mathrm{~F}$ & 43 & $13 \mathrm{~kg}$ & $84.2 \mathrm{~cm}$ & $17.2 \mathrm{~cm}$ & 14.2 & 85 & 17.9 \\
\hline 21 & & $\mathrm{~F}$ & 41 & $12 \mathrm{~kg}$ & $84.5 \mathrm{~cm}$ & $15 \mathrm{~cm}$ & 13.2 & 85.2 & 16 \\
\hline 22 & & $\mathrm{~F}$ & 30 & $11 \mathrm{~kg}$ & $83 \mathrm{~cm}$ & $15 \mathrm{~cm}$ & 12.5 & 89.2 & 16.2 \\
\hline 23 & & $\mathrm{~F}$ & 37 & $12 \mathrm{~kg}$ & $89 \mathrm{~cm}$ & $16 \mathrm{~cm}$ & 13.5 & 91 & 18 \\
\hline 24 & & $\mathrm{~F}$ & 42 & $13 \mathrm{~kg}$ & $85 \mathrm{~cm}$ & $15.2 \mathrm{~cm}$ & 14 & 86 & 17 \\
\hline 25 & & $\mathrm{M}$ & 37 & $12 \mathrm{~kg}$ & $85 \mathrm{~cm}$ & $14 \mathrm{~cm}$ & 12 & 86 & 15 \\
\hline 26 & & M & 60 & $16 \mathrm{~kg}$ & $89 \mathrm{~cm}$ & $17 \mathrm{~cm}$ & 16.2 & 89.7 & 18 \\
\hline 27 & & $\mathrm{~F}$ & 39 & $13 \mathrm{~kg}$ & $82 \mathrm{~cm}$ & $16.4 \mathrm{~cm}$ & 13.5 & 83 & 17 \\
\hline
\end{tabular}




\begin{tabular}{|c|c|c|c|c|c|c|c|c|c|}
\hline 28 & & F & 31 & $12 \mathrm{~kg}$ & $86.2 \mathrm{~cm}$ & $16.6 \mathrm{~cm}$ & 12.5 & 87 & 16.9 \\
\hline 29 & & M & 36 & $12 \mathrm{~kg}$ & $92 \mathrm{~cm}$ & $16.2 \mathrm{~cm}$ & 12.8 & 93 & 17 \\
\hline 30 & M & 48 & $15 \mathrm{~kg}$ & $88 \mathrm{~cm}$ & $16 \mathrm{~cm}$ & 16 & 89.4 & 17.1 \\
\hline 31 & M & 36 & $10 \mathrm{~kg}$ & $68.4 \mathrm{~cm}$ & $14 \mathrm{~cm}$ & 10 & 69 & 14.5 \\
\hline 32 & F & 36 & $13 \mathrm{~kg}$ & $80 \mathrm{~cm}$ & $15 \mathrm{~cm}$ & 14.4 & 81 & 16 \\
\hline 33 & F & 39 & $11 \mathrm{~kg}$ & $69.7 \mathrm{~cm}$ & $14 \mathrm{~cm}$ & 12 & 70.3 & 14.2 \\
\hline 34 & F & 40 & $12 \mathrm{~kg}$ & $90 \mathrm{~cm}$ & $15.4 \mathrm{~m}$ & 12.5 & 91 & 15.9 \\
\hline 35 & F & 48 & $12 \mathrm{~kg}$ & $90.2 \mathrm{~cm}$ & $15 \mathrm{~cm}$ & 13 & 91.9 & 16 \\
\hline 36 & M & 48 & $14 \mathrm{~kg}$ & $85 \mathrm{~cm}$ & $15.3 \mathrm{~cm}$ & 15 & 86 & 16.6 \\
\hline 37 & F & 44 & $14 \mathrm{~kg}$ & $88 \mathrm{~cm}$ & $16.5 \mathrm{~cm}$ & 14 & 88.8 & 17.2 \\
\hline 38 & F & 24 & $12 \mathrm{~kg}$ & $87.1 \mathrm{~cm}$ & $15 \mathrm{~cm}$ & 12.5 & 87.7 & 16 \\
\hline 39 & & M & 24 & $12 \mathrm{~kg}$ & $86 \mathrm{~cm}$ & $15.9 \mathrm{~cm}$ & 13.5 & 87.5 & 16.4 \\
\hline 40 & F & 29 & $10 \mathrm{~kg}$ & $78.5 \mathrm{~cm}$ & $15 \mathrm{~cm}$ & 10.5 & 79.2 & 15.5 \\
\hline 41 & & M & 36 & $13 \mathrm{~kg}$ & $87.1 \mathrm{~cm}$ & $14 \mathrm{~cm}$ & 13.5 & 88 & 14.7 \\
\hline 42 & & M & 24 & $10 \mathrm{~kg}$ & $84 \mathrm{~cm}$ & $14 \mathrm{~cm}$ & 10.2 & 85 & 14.4 \\
\hline
\end{tabular}

\section{Data management and analysis}

Data were recorded in a data form (Tables $2 \& 3$ ) by the health teacher of the CDC and double checked by a health worker. Based on the initial data, the height, weight and MUAC of the children were divided into four categories (Table 4). Baseline and final data were calculated and compared [1,2,9,34]. Data were analysed using the IBM SPSS statistical software (version 22.0).

Table 4: Distribution of weight, height and MUAC before and after the rice pudding programme.

\begin{tabular}{|c|c|c|}
\hline \multicolumn{2}{|c|}{ Distribution of weight prior to the programme } & Weight after programme \\
\hline Weight range (kg) & Prior proportion (\%) & 12 \\
\hline $12-0 c t$ & 33 & 32 \\
\hline $13-15$ & 53 & Height after programme \\
\hline $16-18$ & 14 & Proportion (\%) \\
\hline Distribution of height prior to the programme & 5 \\
\hline Height range (cm) & Proportion (\%) \\
\hline $68-75$ & 5 & 7 \\
\hline $76-83$ & 10 & 55 \\
\hline $84-91$ & 64 & 33 \\
\hline $92-98$ & 21 & MUAC after programme \\
\hline \multicolumn{1}{|c|}{ Distribution of MUAC prior to programme } & Proportion (\%) \\
\hline MUC range (cm) & Proportion (\%) & 38 \\
\hline $14-16$ & 57 & 62 \\
\hline
\end{tabular}

\section{Rice pudding feeding impacts on children}

The majority of the participants were female (57\%) with a mean age of 44.7 months. A plurality was between $46-50$ months (31\%), followed by 36-40 months (22\%) and 51-55 months (21\%). Only $2 \%$ of children were between 31-35 months (Table 3). The $16-18 \mathrm{~kg}$ weight group of the children of the total children have significantly gained their weight from $14 \%$ to $36 \%$. But 13-15 kg weight group children could not increase their weight (53\% vs. 52\%) after the rice pudding (Table 4).

The height data showed significant differences between baseline survey data and final data (Tables 3 \& 4). Among 42 children participating, the weight of 38 children increased, whilst four maintained their weight. Similarly, 33 children increased in height and nine children demonstrated a small increment in height. Also, an increment in MUAC was found in 37 students while slight increment was found in the remaining 5 children (Tables $3 \& 4$ ). The study data showed significant improvements in the BMI of the children (Tables 3 \& 4). MUAC measurement was categorized into two groups (Table 4). The proportion in the higher category had changed significantly from pre-programmed to post-intervention; overall $19 \%$ of the children increased their MUAC during the period of the intervention (Tables $3 \& 4$ ). Figure 1 show the result of the baseline results which were measured before the pilot study (left side) and after the pilot study (right side). 


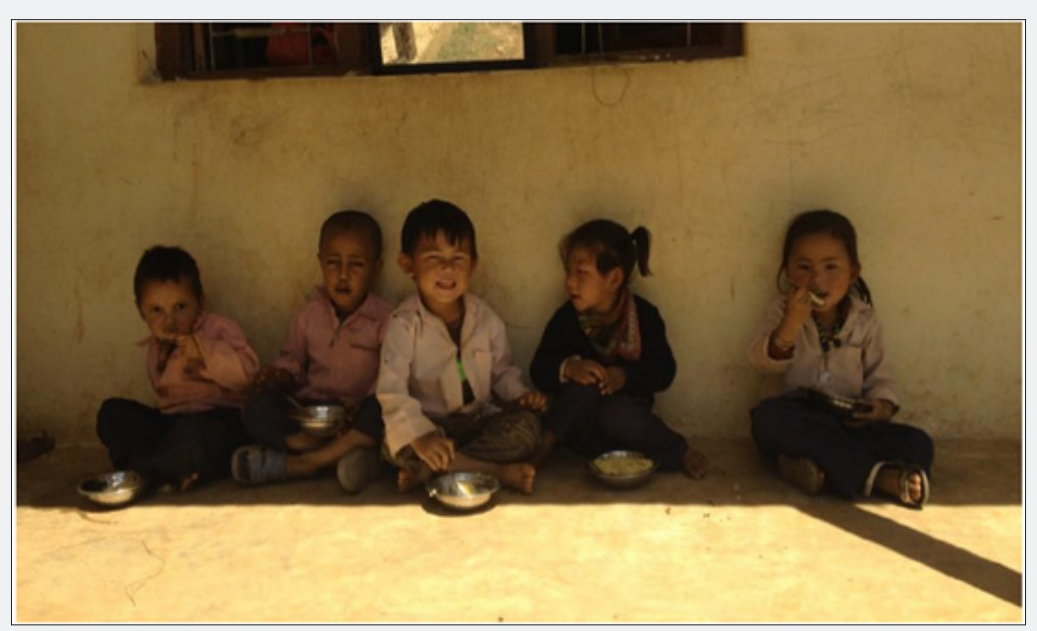

Figure 1: Children are enjoying rice pudding at the daycare centre.

\section{Discussion}

A free rice pudding was provided six days a week for two months at Jugal Child Development Centre, for children aged 2-5 years in an area with high levels of poverty [35]. Results indicated that this intervention enabled households to increase their expenditure on nutritious food items and spend less on junk foods [20,24]. A significant increase in daycare centre enrolment and in continuing education is also associated with the programme [12,35]. In Nepal, the impact of the rice pudding has not been studied extensively [30]. The rice pudding is termed 'Khir' in Nepali language and accepted by all local religious and ethnic groups. Khir is also one of the popular recipes amongst the children and a nutritionally recommended food item [19,36]. Adding butter (ghee), sugar, raisins and other ingredients to rice pudding increases its nutritional value in terms of energy nutrients and improves its sensory acceptability [36]. Khir is easy to prepare, with an associated low cost [37]. This study has empowered parents and members of the community to intervene in food behaviours and thus have an impact on improving children's health and potentially have a beneficial effect on their 8 education. This intervention has played a vital role for increasing the knowledge about a healthy diet amongst mothers, teachers, health workers and executive members of the CDC [35] which might be accepted by policy makers and various donor groups.

The study identified significant increases in children's weight, height and MUAC (Tables 3 \& 4) and improved knowledge about a healthy diet amongst the parents [35,37]. Similarly, considering the growth of the children after introduction of school meals, de Onis et al. [37] describe the significant growth of under-five children (Figure 1), an outcome similar to the one observed in this pilot study (Figure 2). A study conducted in Ghana by Abizari et al. [34] indicated an important role for micronutrient-dense foods in the achievement of micronutrient adequacy within school feeding programmes, something our study also described (Figures 2 \& 3). Abizari's cohort additionally showed that nutritional dietary intake was remarkably higher and more sufficient among children participating in a school feeding plan. Singh et al. [17] conducted a study on children whose families' income suffered from drought; their work reported that the school meal programme acted as a safety net for children, whose health was significantly improved [17]. However, our study also reflected the similar results (Table 2) as Singh et al. [17] highlighted in his study as well as Gleason and Dodd [24].

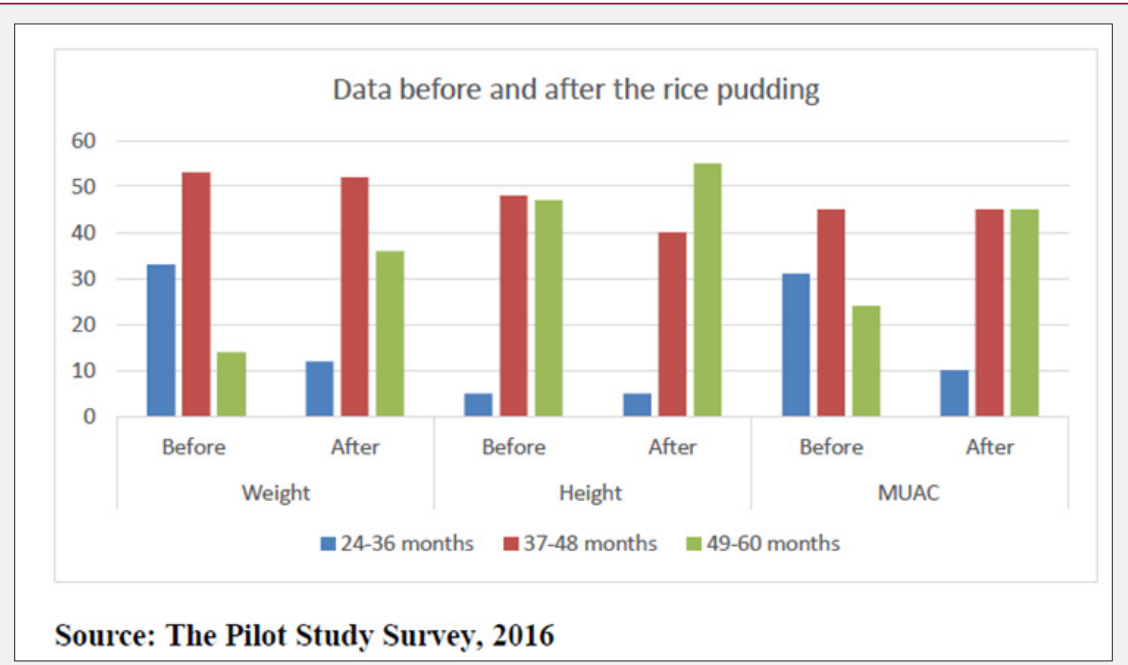

Figure 2: Baseline and final evaluation of the pilot study. 


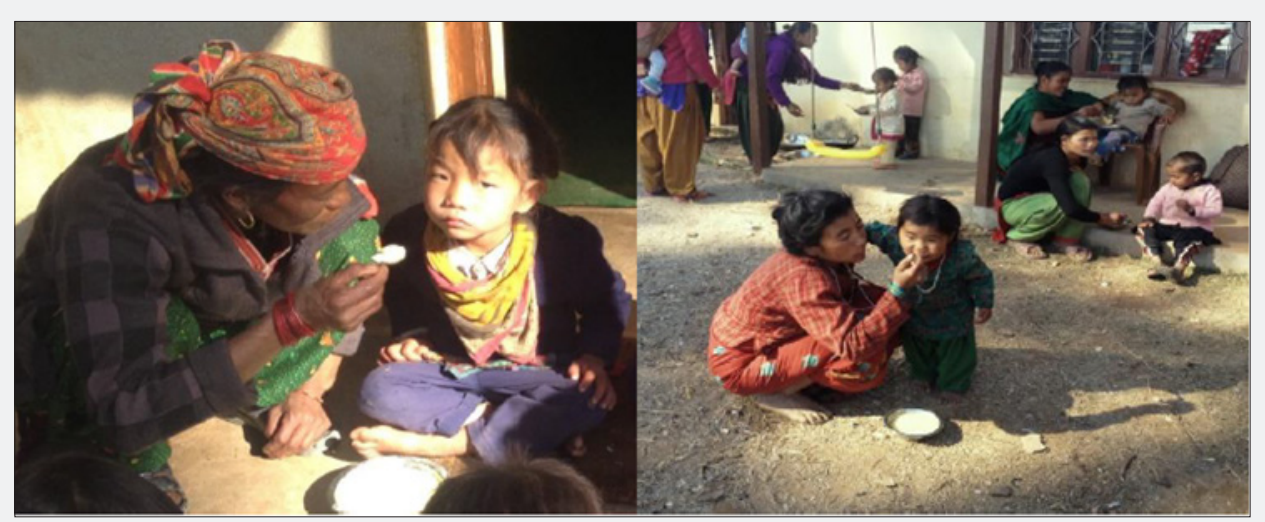

(A)

(B)

Figure 3: (A) Mother is helping to feed rice pudding, (B) A child is being fed by mother.

A study looking at how school meal participation influences students' weight status, concluded that there was no evidence that either the school snacks (SS) or meal programmes contributed to rising BMI in school children [38]. The authors report that an increase of a single day in the normal school snack programme sharing was linked with a reduction of 0.15 in BMI [35]. They also added that SS package participation may be a protective issue, by encouraging children to take the SS or meal regularly. However, our study also finds poor increment of BMI in the participants (Tables 3 $\& 4$ ), which may be due to the small sample and short duration. A few questions arise from this pilot intervention, particularly the impact on educational performance, which is not addressed. Baxter et al. [16] report one observational study among fourth-grade children which demonstrates a significant increase in calorie intake upon participation in the school snack [9]. Programme in the classroom compared to those who ate it in the canteen [16]. In our study, all the participants' parents were living under the poverty line and had poor knowledge about a healthy diet $[2,4,11,12]$. Therefore, they were not capable to provide a healthy food to their children at home which rice pudding programme showed significant improvement in the child health (Tables $3 \& 4$ ).

The benefit of the approach used here is the link between supporting children's education while enhancing their food security $[31,39]$. The study confirmed that the programme was remarkably cost-effective and significantly successful in terms of growth of BMI $[6,14,39]$. The study's key message is that a longer course of the healthy food certainly would bring drastic changes in children's BMI $[13,34]$. For example, six months rice pudding programme, instead of two months, would play a vital role on child health $[13,34]$.

\section{Cost of the Intervention}

Healthy foods are expensive for poor people in Nepal $[11,26,27,39]$. Children are compelled to consume whatever food is prepared for the parents due to various factors such as poverty, poor knowledge on child feeding practices, time constraints, and poor resources $[40,19,23]$. Local participation is part of the development of ownership and community involvement and further contributes to the cost-effectiveness of the intervention, which favours its sustainability $[11,12,17,27,36,39]$. This study has also demonstrated an example of the community mobilization, partnership and ultimately cost-effectiveness of the programme. This study showed the cost per portion/per child/per day was US $\$ 0.34$ including commodity costs and USD 14.36/day for 42 children [11,19]. A financial analysis by WFP12 explained why school meals/snacks costs are so inconsistent. WFP (2013)12 study found that the commodity costs were generally the main cost component and these varied. For example, Curtis et al. [39]. gathered the information that the actual cost of a school meals/ snack around the Europe, USA and Australia which demonstrated a very high cost than this study such as Scotland USD 2.94, Sweden USD 2.66, USA USD 2.0 and Australia 10 USD 2.32 respectively. The partnership with the local community affects three key areas impact: cost-effectiveness, ownership and sustainability of the programme. This offers an acceptable and innovative approach towards scaling up nutrition within the community.

\section{Study Strengths and Limitations}

This study is part of a successful partnership programme between the CDC and researcher, driven by the local institution, and offers a practical application of food behaviour and environmental level change [11,33,27,37,32]. This study used a participatory approach which reduced the cost of the programme by using the local resources Likewise the local community economy was supported with the utilization of the local resources [14,27,32]. Still, this pilot study has acknowledged weaknesses. The intervention was limited to eight weeks, but lessons learnt are likely to be applicable to other poor communities in Nepal. A few children reportedly suffered from vomiting and diarrhoea after eating the rice pudding, which was probably due to weak digestive systems, or food intolerance, but would need to be considered if scaling up.

\section{Conclusions}

The school meal programme plays a crucial role in the diets of children in poor families by providing free snacks $[10,11,17,14]$. This pilot study resulted in progressive changes in the health of children and helped to increase awareness among the mothers regarding healthy dietary habits. School meals should include fruits, vegetables and calcium-rich dairy beverages and foods to enhance their nutritional content and contribution and increase child access and exposure to nutritious meal options; however, this carries a cost implication. This programme is ideally suited to high-poverty 
areas where it can contribute to the child's daily dietary intake. The study attracted modest charitable donations from the public to fund it [41] and this is recommended as this could help initiate similar interventions in resource-poor areas and enable sustainability. This study contributes to the evidence for policy and practice in relation to school meals/snacks programmes that positively contribute to improving community food behaviour and to national nutrition programme aims and the achievement of sustainable development goals $[4,9,15]$.

\section{Ethical Approval}

The District Public Health Office and District Education Office of Sindhupalchowk of Nepal have given ethical permission for this study and consent were obtained from all parents and guardians prior to the rice pudding distribution programme $[8,28,29]$. The author applied ethical approval from the local government authority where this study did not involve that are of high risk for the participants and also this study is not involved in any specimens, tissue samples or vertebrate animals, embryos or tissues. Prior to starting the study, the corresponding author had taken consent from his supervisory team, who reviewed the study proposal with Bournemouth University. On the other hand, there were no any risks occurred during the data collection. The researchers and management team had paid high attention on any occurrence. First Aid Kit was placed at all the data collection area to tackle minor injury and provide some pain relief tablets. In case of some incidence occurred at the feeding place, the ambulance will be called and patient will be sent to the nearest health institutions for the further treatment. The participants did not expose to any risks by participating in the study $[42,43]$.

\section{Acknowledgement}

The authors would like to convey their sincere thanks to the Jugal Child Development Centre, the District Public Health Office, and the District Education Office of the Sindhupalchowk district for their support and positive response during the study. Funding arrangements are as described in Table 5 [11].

\section{Financial Report}

This research project received no specific grant from any funding agency, commercial or not-for-profit sector. The author has picked up money (collected) from the road and streets and subsidized material costs by the local community (Table 5).

Table 5: Sources of funding.

\begin{tabular}{|c|c|c|c|}
\hline Source & Total (NRs.) & Total (US\$) & Remarks \\
\hline Contribution by the researcher & & & $\begin{array}{c}\text { In two and half years, the first } \\
\text { author collected dropped money } \\
\text { (mainly coins) while walking in } \\
\text { the streets (Geoghegan, 2008). } \\
\text { His friends and relatives also } \\
\text { contributed (nearly 5\%) to } \\
\text { this programme. }\end{array}$ \\
\hline Contribution by the local people & $48,000.00$ & 459.59 & $\begin{array}{c}\text { Supported by the local management } \\
\text { of snack distribution programme, } \\
\text { local }\end{array}$ \\
\hline Total & $33,000.00$ & 315.97 & $\begin{array}{c}\text { community people including CDC. } \\
\text { com }\end{array}$ \\
\hline
\end{tabular}

\section{References}

1. Sellen D (1998) Physical Status: The Use and Interpretation of Anthropometry. Report of a WHO Expert Committee. WHO Technical Report Series No. 854 Journal of Biosocial Science 30(1): 135-144.

2. Gabriele A, Schettino F (2008) Child Malnutrition and Mortality in Developing Countries: Evidence from a Cross-Country Analysis. Analyses of Social Issues and Public Policy 8(1): 53-81.

3. Bowden F, Lordly D, Thirsk J, Corby L (2012) Phase II Practice-based Evidence in Nutrition (PEN) Evaluation: Interviews with Key Informants. Canadian Journal of Dietetic Practice and Research 73(1): e233-e240.

4. Haddad L, Cameron L, Barnett I (2015) The double burden of malnutrition in SE Asia and the Pacific: priorities, policies and politics. Health Policy and Planning 30(9): 1193-1206.

5. SACN (2015) Dietary Recommendations for Energy [Internet]. Scientific Advisory Committee on Nutrition.

6. Dearden L, Farquharson C (2017) Free school meals for all primary pupils: Projections from a pilot.

7. (2012) Food and Nutrition Service. Proposed Rules Nutrition Standards in the National School Lunch and School Breakfast Programs.

8. Crepinsek M, Singh A, Bernstein L, McLaughlin J (2006) Dietary Effects of Universal-Free School Breakfast: Findings from the Evaluation of the School Breakfast Program Pilot Project. Journal of the American Dietetic Association 106(11): 1796-1803.

9. Afridi F (2011) The Impact of School Meals on School Participation: Evidence from Rural India. Journal of Development Studies 47(11): 1636-1656.

10. Sørensen L, Dyssegaard C, Damsgaard C, Petersen R, Dalskov S, et al. (2015) The effects of Nordic school meals on concentration and school performance in 8- to 11-year-old children in the OPUS School Meal Study: a cluster-randomised, controlled, cross-over trial. British Journal of Nutrition 113(08): 1280-1291.

11. WFP (2013) State of School Feeding Worldwide, United Nations World Food Programme-Fighting Hunger Worldwide. Wfp.org.

12.WFP (2016) Two Minutes to Learn about School Meals | WFP | United Nations World Food Programme - Fighting Hunger Worldwide Wfp.org. 
13. Kumanyika S, Grier S (2006) Targeting Interventions for Ethnic Minority and Low-Income Populations. The Future of Children 16(1): 187-207.

14. (2014) UNESCO. Sustainable development begins with education | United Nations Educational, Scientific and Cultural Organization. Unesco.org

15. Best C, Neufingerl N, Del Rosso J, Transler C, van den Briel T, et al. (2011) Can multi-micronutrient food fortification improve the micronutrient status, growth, health, and cognition of schoolchildren? A systematic review. Nutrition Reviews 69(4): 186-204.

16. Baxter S, Hardin J, Guinn C, Royer J, Mackelprang A, et al. (2010) Children's body mass index, participation in school meals, and observed energy intake at school meals. International Journal of Behavioral Nutrition and Physical Activity 7(1): 24.

17. Singh A, Park A, Dercon S (2014) School Meals as a Safety Net: An Evaluation of the Midday Meal Scheme in India. Economic Development and Cultural Change 62(2): 275-306.

18. Kristjansson E, Gelli A, Welch V, Greenhalgh T, Liberato S, et al. (2016) Costs, and cost-outcome of school feeding programmes and feeding programmes for young children. Evidence and recommendations. International Journal of Educational Development 48: 79-83.

19. Moock P, Leslie J (1986) Childhood malnutrition and schooling in the Terai region of Nepal. Journal of Development Economics 20(1): 33-52.

20. Arain M, Campbell M, Cooper C, Lancaster G (2010) What is a pilot or feasibility study? A review of current practice and editorial policy. BMC Medical Research Methodology 10(1).

21. (2018) Sindhupalchok An overview of the Sindhupalchok District. En.wikipedia.org.

22. Child Nepal(2018) An overview of Child Nepal: Initiating a child friendly culture. childnepal.org.

23. Gelli A (2015) School Feeding and Girls' Enrollment: The Effects of Alternative Implementation Modalities in Low-Income Settings in SubSaharan Africa. Frontiers in Public Health 3: 76.

24. Gleason P, Dodd A (2009) School Breakfast Program but Not School Lunch Program Participation Is Associated with Lower Body Mass Index. Journal of the American Dietetic Association 109(2): S118-S128.

25. van Teijlingen E, Hundley V (2005) Pilot studies in family planning and reproductive health care. Journal of Family Planning and Reproductive Health Care 31(3): 219-221.

26. Ireland K (2017) Is Rice Pudding Healthy? LIVESTRONG.COM

27. Ludwig D, Peterson K, Gortmaker S (2001) Relation between consumption of sugar-sweetened drinks and childhood obesity: a prospective, observational analysis. The Lancet 357(9255): 505-508.

28. Bradbury J, Nelson M, Erens R, Bates B, Church C, et al. (2013) Summary of: Sugars consumption in a low-income sample of British young people and adults.British Dental Journal 215: 26-27.

\section{ISSN: 2574-1241}

DOI: 10.26717/BJSTR.2018.06.001346

Jib Acharya. Biomed J Sci \& Tech Res

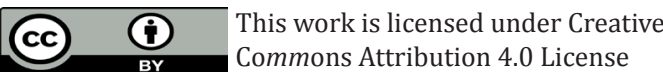

Submission Link: https://biomedres.us/submit-manuscript.php
29. van Teijlingen E, Rennie A, Hundley V, Graham W (2001) The importance of conducting and reporting pilot studies: the example of the Scottish Births Survey. Journal of Advanced Nursing 34(3): 289-295.

30. Devkota M, Uprety A, Subedi N, Paudel R (2012) Identification of Gaps and Priority Interventions for Maternal Nutrition in Nepal: A Review Dohs.gov.np

31. Butchon R, Liabsuetrakul T (2017) The Development and Growth of Children Aged under 5 years in Northeastern Thailand: a Cross-Sectional Study. Journal of Child and Adolescent Behaviour 5: 1.

32. Acharya J, Van Teijlingen E, Murphy J, Hind M (2017) Food belief practices amongst rural and urban mothers in Nepal: A qualitative overview.

33. O’Dea J, Peter Caputi (2001) Association between socioeconomic status, weight, age and gender, and the body image and weight control practices of 6- to 19-year-old children and adolescents. Health Education Research 16(5): 521-532.

34. Abizari A, Buxton C, Kwara L, Mensah-Homiah J, ArmarKlemesu M, et al. (2014) School feeding contributes to micronutrient adequacy of Ghanaian schoolchildren. British Journal of Nutrition 112(06): 10191033.

35. Gakidou E, Cowling K, Lozano R, Murray C (2010) Increased educational attainment and its effect on child mortality in 175 countries between 1970 and 2009: a systematic analysis. The Lancet 376(9745): 959-974.

36. (2009) UNICEF. Tracking Progress on Child and Maternal Nutrition: A survival and development priority. Unicef.org.

37. de Onis M, Onyango A, Borghi E, Garza C, Yang H(2006) Comparison of the World Health Organization (WHO) Child Growth Standards and the National Center for Health Statistics/WHO international growth reference: implications for child health programmes. Public Health Nutrition 9(07): 942-947.

38. Gertler P, Heckman J, Pinto R, Zanolini A, Vermeersch C, et al. (2014) Labor market returns to an early childhood stimulation intervention in Jamaica. Science 344(6187): 998-1001.

39. Curtis P, Henley J, Lennard J, McCurry J, Tran M, et al. (2005) School meals around the world The Guardian.

40. Gordon A, Cohen R, Crepinsek M, Fox M, Hall J, et al. (2009) The Third School Nutrition Dietary Assessment Study: Background and Study Design. Journal of the American Dietetic Association 109(2): S20-S30.

41. Karimi M (2017) UN World Food Programme. Wfp.org.

42. Luo R, Shi Y, Zhang L, Liu C, Rozelle S, et al. (2012) Nutrition and Educational Performance in Rural China's Elementary Schools: Results of a Randomized Control Trial in Shaanxi Province. Economic Development and Cultural Change 60(4): 735-772.

43. Devakumar D, Kular D, Shrestha B, Grijalva-Eternod C, Daniel R, et al. (2017) Socioeconomic determinants of growth in a longitudinal study in Nepal. Maternal \& Child Nutrition 14(1): e12462.

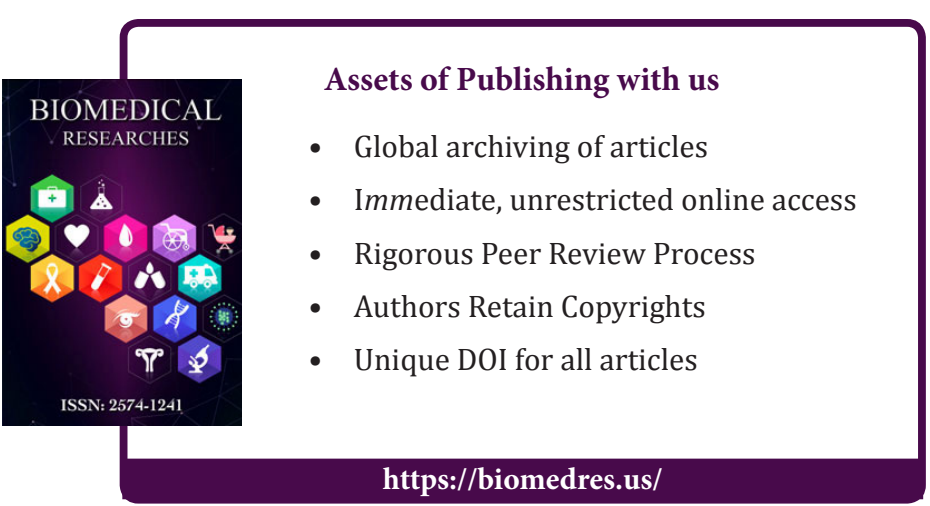

Cite this article: Acharya J, van Teijlingen E, Ellahi B, Pariyar B, Subedi K et al. Impact of Rice Pudding on Preschool-Aged Children's Health: an Overview of a Pilot Study. Biomed J Sci\&Tech Res 6(3)- 2018. BJSTR. MS.ID.001346. DOI: 10.26717/ BJSTR.2018.06.001346. 